\title{
STUDENT-SUPERVISOR-UNIVERSITY EXPECTATION ALIGNMENT IN THE UNDERGRADUATE ENGINEERING THESIS
}

\author{
Brad Stappenbelt iD, Abheek Basu 1 D \\ School of Mechanical, Materials and Mechatronic Engineering, Faculty of Engineering \\ and Information Sciences, University of Wollongong (Australia) \\ brads@uow.edu.au,abheek@uow.edu.au
}

Received May 2018

Accepted October 2018

\section{Abstract}

Given the lack of student research experience, the undergraduate thesis is necessarily focussed primarily on development of research skills (i.e. it is process oriented). Since postgraduate supervision is research output focussed, the lessons learnt from this field are not always directly transferable. In contrast to the vast body of work in the field of doctoral research supervision, there exists a dearth of literature on undergraduate dissertation supervision. To address this shortcoming, the present study examined the alignment of university, supervisor and student expectations regarding responsibilities in the undergraduate engineering thesis. University expectations, having undergone rigorous review, outline the sound pedagogical practice that should be applied to undergraduate supervision. Expectations of academic staff supervisors and thesis students were obtained through the use of survey tools and postsurvey discussions. The surveys used in the present study were adapted from the Role Perceptions Rating Scale (RPRS). Alignment between student and university expectations regarding undergraduate thesis responsibilities in the present study was generally poor. The discrepancy between supervisor and university expectations was even greater, with academic staff generally assuming the bulk of the responsibility for many core thesis tasks. Post-survey discussion indicated that the driver for this behaviour were supervisor expectations that undergraduate thesis research would contribute to publications. Taking primary responsibility for core thesis tasks away from the student, although improving the likelihood of successful research output, diminishes the ability for an accurate assessment of adequate academic performance. The learning that is intended to result from the undergraduate thesis is devalued when research outcomes are prioritised over research process.

Keywords - Undergraduate thesis, Thesis supervision, Supervision responsibilities, Thesis student expectations, Thesis pedagogy.

\section{To cite this article:}

Stappenbelt, B., \& Basu, A. (2019). Student-supervisor-university expectation alignment in the undergraduate engineering thesis. Journal of Technology and Science Education, 9(2), 199-216. https://doi.org/10.3926/jotse.482 


\section{Introduction}

The formal thesis or research project has long been considered an integral component of the bachelor degree curriculum at higher education institutions (Cornwall, Schmithals \& Jacques, 1977; Brew \& Jewell, 2012; Brew, 2013; Brew \& Mintai, 2017, Lee \& Loton, 2017). The Australian Qualifications Framework specifies that completion of a dissertation is a necessary requirement for the attainment of honours level degree in Australia (Australian Qualifications Framework Council, 2013). In order to increase the quality of the undergraduate educational experience, research-based education has also been advocated for some time in the USA (Boyer Commission, 1998) and there has also been more recent growth in the adoption of the undergraduate thesis in Europe (Vera \& Briones, 2015).

The modern university arguably defines itself on the basis of the teaching-research nexus (Stappenbelt, 2013). Despite this view, the teaching-research nexus study by Stappenbelt (2013), examining student benefit from this exchange, showed that during most of their coursework, students do not recognise the effect of the nexus, nor do they appear to benefit greatly from it. The thesis subject then, constitutes one of the few opportunities in which the research activities of staff can directly and meaningfully impact their teaching. Despite arguments that research skill development is poorly aligned with the vocational needs of most students, the prominence of the teaching-research nexus in the undergraduate thesis remains a powerful driver for retaining the dissertation as the capstone of the honours degree (Malcolm, 2012).

Post-graduate research and supervision has to date received a great deal of attention in the literature (e.g. Lessing, 2011; Hussain, 2011; Sahoo \& Mazid, 2009; Brown \& Krager, 1985; Mudaly, 2012). There are numerous papers, spanning more than a few decades, detailing supervision theory and professional practice. Alternative methods of doctoral thesis completion have been investigated (e.g. Lee, Clark \& Thompson, 2013) and improvements in supervision techniques trialled (e.g. Chin, Spowage, Yap \& Lee, 2011; Gatfield, 2005). The learning benefits of supervision for supervisors have even been evaluated (e.g. Halse, 2011). The vast amount of literature regarding doctoral supervision might suggest that research supervision in general has already been adequately investigated. Although there are undoubtedly many aspects of postgraduate research supervision that are transferable to undergraduate thesis supervision, there exist some very significant differences.

Undergraduate students have very little research experience (Cook, 1980). The study by Lovitts (2005) for example, demonstrated the difficulties students encounter transitioning from coursework to independent research. The lack of prior research exposure and acquisition of the associated skills is exacerbated by the notably shorter timeframe (Rowley \& Slack, 2004) of the undergraduate thesis. One of the most significant shifts in student mindset that needs to occur is to move from directed learning in large group settings to autonomous learning under the guidance of a supervisor as discussed in the work by Stappenbelt (2013) and Day and Bobeva (2007). These factors imply that the undergraduate thesis focus must necessarily be the development of research skills rather than research output. As a novel contribution to a body of knowledge, in the form of research output, is the ultimate focus of postgraduate research, this difference then limits the transferability of doctoral supervision literature to the undergraduate thesis context (Kiley, Boud, Manathunga \& Cantwell, 2011).

In contrast to the well-studied field of postgraduate supervision, Rowley and Slack (2004) conclude that there is a scarcity of literature on undergraduate dissertation supervision. There is certainly no lack of support for this position (e.g. Kiley, Boud, Cantwell \& Manathunga, 2009; Derounian, 2011; Kiley \& Cumming, 2014) including the recent study by Roberts and Seaman (2018: page 28) which agrees that "the practice of undergraduate dissertation supervision is an understudied and under-resourced area of higher education". Honours pedagogy in general is described as "relatively invisible and unarticulated" (Kiley et al. 2009: page 4). Despite academic thesis supervisors being fully indoctrinated in research methodology through their own doctoral studies, the study by Holmberg (2006) showed that there exists much variation in supervisor understanding and implementation of their roles in undergraduate research. This study concluded that there appears to be a lack of common frame of reference for 
supervision requirements of the undergraduate thesis. In a study examining various mechanisms by which supervisory arrangements fail, Ladany (2014) concurs with this position. Ladany (2014: page 1102) suggests that current undergraduate thesis research supervision is only effective and in about $11 \%$ of cases, concluding that "supervisor training in theoretical and practical approaches to supervision is essential".

In the current era of immense publication pressure on academics (see Grimes, 2018) for an overview of the publish-or-perish state of academia), an area of growing concern relates to publications arising from undergraduate theses. The review by Fanelli (2009) reported that questionable research practices are contributing to as much as $75 \%$ of all research publications. The minority of these reported cases are a result of outright fraudulent behaviour. The vast majority, with academics under enormous time and other resource demands, are attributed to sloppy research practices. A key avenue through which these questionable research outputs are produced is through the intensive utilisation of student labour with insufficient quality controls and supervision. One of the six major threats to good supervision of undergraduate dissertations identified by Roberts and Seaman (2018: page 31) is staff that are "overworked and pressured to publish". The interviews conducted as part of this study concluded that "it is not surprising that some academics view honours and other undergraduate dissertation students as unpaid research assistants" (Roberts \& Seaman, 2018: page 37). Some supervisors interviewed confirmed taking advantage of students to collect data solely for the purpose of producing research publications, expressing full awareness that this practice resulted in little benefit to students in terms of research skill development (Roberts \& Seaman, 2018). In a study examining the implications of student and supervisor perceptions of undergraduate research, Malcolm (2012) also raises the concern that research outcomes are being prioritised over research process, devaluing the learning that is intended to result.

Doctoral dissertations are widely acknowledged as contributing meaningfully to research output (Evans, 2007). The quality of this research is generally acceptable since supervisors of doctoral students require training (Australian Qualifications Framework Council, 2013), the students have commonly been exposed to research methodology through involvement in prior research and high levels of scrutiny of the degrees awarded are implemented at several levels institutionally (Evans, Lawson, McWilliam \& Taylor, 2005). In contrast, undergraduate supervisors require no training and the supervision proceeds with limited scrutiny and accountability of the practices employed (Kiley et al., 2009). In light of the lower prospect of research publications resulting from undergraduate research, Kiley et al. (2011) report supervisor perceptions that undergraduate supervision is less rewarding than postgraduate research supervision.

Roberts and Seaman (2018) strongly advocate clarifying student and supervisor expectations prior to commencement of the thesis. This sentiment was echoed in the work by Derounian (2011) where supervisor-student contracts were also advised in an effort to move toward good undergraduate thesis supervision practice. In both of these studies, the list of 'good' supervisor traits reported by students and staff are very useful in refining the development of supervisory practice however, they are not mapped to any pedagogical framework for teaching the student to undertake a thesis. Jamieson and Gray (2006), using a modified Student Perception of Research Supervision survey developed at the University of Western Australia, quantitatively investigated the level of disparity in student $(\mathrm{n}=36)$ and supervisor expectations. Although the study concluded that the expectations of both parties were reasonable well matched (despite some noteworthy deviations), there was again, no reference to a pedagogical framework. Agreement in expectations regarding thesis supervision is beneficial to the student only if these align with good supervision practice. Before looking at the qualities associated with 'good' supervision practices, a footing in sound pedagogy needs to be established. Any proposed contract that clarifies thesis expectations should then be based on well-defined and accepted thesis objectives (Cook, 1980). 


\section{Methodology}

The aim of the present study was to examine the alignment of university, supervisor and student expectations regarding each party's responsibilities during the undergraduate engineering thesis. The undergraduate engineering thesis at the University of Wollongong (UoW) is a traditional final-year capstone annual subject as defined by Cook (1980). It follows a largely pre-determined structured course in fundamental engineering principles and practices (Cornwall et al., 1977).

The university's expectations regarding the undergraduate engineering thesis are defined as those stated in the teaching and learning university policy documents, the thesis subject learning outcomes and accompanying university engineering thesis handbook (UoW Engineering Thesis handbook, 2017). These documents have undergone rigorous review at school, faculty education committee, course development committee and academic senate levels to ensure that sound pedagogical practices are employed. All degrees in Australia must also demonstrate compliance with the Australian Qualifications Framework (Australian Qualifications Framework Council, 2013). Engineers Australia accreditation of the degrees in which the thesis is conducted ensures that this then also aligns with the expectations of the governing body for engineering in Australia.

The UoW Faculty of Engineering and Information Sciences thesis subject learning outcomes are (UoW Engineering Thesis handbook, 2017: page 7):

(i) Define clearly the aims and objectives of a given problem.

(ii) Retrieve and analyse previous work on related problems (critical literature review).

(iii) Formulate methods for problem solution.

(iv) Plan, design and construct an experimental or theoretical procedure to solve the problem.

(v) Collect data and evaluate findings.

(vi) Communicate conclusions and solutions verbally and in writing.

These six learning outcomes map almost directly to the six learning objectives described by Cook (1980) as defining the fundamental goals of the undergraduate dissertation in science and engineering.

Expectations of supervising staff and thesis students were examined through the use of survey tools and post-survey discussions. The surveys used in the present study were adapted from the Role Perceptions Rating Scale (RPRS) used by Aspland, Edwards, O'Leary and Ryan (1999) and Ryan and Whittle (1997). This survey was based on the work by Moses (1985). The original survey instrument has previously been employed to investigate doctoral student perceptions of the student-supervisor relationship in the areas of general management (Lessing, 2011) and education (McPhail \& Erwee, 2000). Each item in the current survey implementation features statements mapped to a numerical response rating scale of -2 through 2 (see Table 1). Negative responses to a survey item indicate that the associated tasks are predominantly the responsibility of the supervisor. Positive responses indicate that the tasks are predominantly the student's responsibility. Zero is the neutral response, indicating the expectation that responsibility is shared equally. Survey item 5 varies from this interpretation of the scale by examining the type of relationship expected by supervisor and students instead.

Additional information collected through the student survey was gender and domestic/international student status. Thesis supervisors were also asked to provide their academic level and an indication of their research supervision experience. The response categories utilised for this purpose (as displayed in Table 2) are 1 (0-10 thesis student supervisions), 2 (11-20 thesis student supervisions) or 3 (> 20 thesis supervisions). All level B supervisors surveyed were in supervision experience category 1 . This result is probably due to the limited supervision opportunity academic staff members have access to prior to commencement of their appointment. Supervising academics at level C indicated the largest range, with supervision experience generally steadily increasing with academic seniority. Interestingly, the spread of 
responses remains large at all academic levels above $\mathrm{B}$, with some supervisors at level $\mathrm{E}$ reporting a cumulative count throughout their careers of less than 10 students supervised.

\begin{tabular}{|c|c|c|c|c|c|c|c|}
\hline Item & Supervisor responsibility & -2 & -1 & $\begin{array}{c}0 \\
\text { (Equal/shared } \\
\text { responsibility) }\end{array}$ & 1 & 2 & Student responsibility \\
\hline 1 & $\begin{array}{l}\text { It is the supervisor's } \\
\text { responsibility to select a } \\
\text { promising topic }\end{array}$ & & & & & & $\begin{array}{l}\text { It is the student's } \\
\text { responsibility to select a } \\
\text { promising topic }\end{array}$ \\
\hline 2 & $\begin{array}{l}\text { It is up to the supervisor to } \\
\text { decide which theoretical frame } \\
\text { of reference is most } \\
\text { appropriate }\end{array}$ & & & & & & $\begin{array}{l}\text { The student has a right to } \\
\text { choose a theoretical } \\
\text { standpoint even if it conflicts } \\
\text { with that of the supervisor }\end{array}$ \\
\hline 3 & $\begin{array}{l}\text { The supervisor should direct } \\
\text { the student in the development } \\
\text { of an appropriate research plan }\end{array}$ & & & & & & $\begin{array}{l}\text { The student should work out } \\
\text { a schedule and research plan } \\
\text { appropriate to their needs }\end{array}$ \\
\hline 4 & $\begin{array}{l}\text { The supervisor should ensure } \\
\text { that the student has access to } \\
\text { all necessary facilities }\end{array}$ & & & & & & $\begin{array}{l}\text { The student must find the } \\
\text { necessary facilities to } \\
\text { complete their research }\end{array}$ \\
\hline 5 & $\begin{array}{l}\text { Supervisor-student } \\
\text { relationships are purely } \\
\text { professional and personal } \\
\text { relationships should not } \\
\text { develop }\end{array}$ & & & & & & $\begin{array}{l}\text { Close personal relationships } \\
\text { are essential for successful } \\
\text { supervision }\end{array}$ \\
\hline 6 & $\begin{array}{l}\text { The supervisor should initiate } \\
\text { frequent meetings with the } \\
\text { student }\end{array}$ & & & & & & $\begin{array}{l}\text { The student should initiate } \\
\text { meetings }\end{array}$ \\
\hline 7 & $\begin{array}{l}\text { The supervisor should check } \\
\text { constantly that the student is } \\
\text { on track and working } \\
\text { consistently }\end{array}$ & & & & & & $\begin{array}{l}\text { Students are entirely } \\
\text { responsible for how they } \\
\text { spend their time and should } \\
\text { monitor their own progress }\end{array}$ \\
\hline 8 & $\begin{array}{l}\text { The supervisor should } \\
\text { determine whether to } \\
\text { terminate the supervision if } \\
\text { they think the student will not } \\
\text { succeed }\end{array}$ & & & & & & $\begin{array}{l}\text { The supervisor should } \\
\text { support the student } \\
\text { regardless of their opinion } \\
\text { of the student's capability } \\
\text { (i.e. the students should } \\
\text { determine whether to } \\
\text { terminate) }\end{array}$ \\
\hline 9 & $\begin{array}{l}\text { The supervisor should ensure } \\
\text { that the thesis is finished on } \\
\text { time }\end{array}$ & & & & & & $\begin{array}{l}\text { The student should ensure } \\
\text { that the thesis is finished on } \\
\text { time }\end{array}$ \\
\hline 10 & $\begin{array}{l}\text { The supervisor has direct } \\
\text { responsibility for the } \\
\text { methodology and content of } \\
\text { the thesis }\end{array}$ & & & & & & $\begin{array}{l}\text { The student has total } \\
\text { responsibility for ensuring } \\
\text { that the methodology and } \\
\text { content are appropriate for } \\
\text { the thesis }\end{array}$ \\
\hline 11 & $\begin{array}{l}\text { The supervisor should assist in } \\
\text { the writing of the thesis if the } \\
\text { student has difficulties }\end{array}$ & & & & & & $\begin{array}{l}\text { The student must take full } \\
\text { responsibility for the writing } \\
\text { of the thesis }\end{array}$ \\
\hline 12 & $\begin{array}{l}\text { The supervisor should insist on } \\
\text { seeing drafts of every section } \\
\text { of the thesis in order to review } \\
\text { them in a timely fashion }\end{array}$ & & & & & & $\begin{array}{l}\text { It is up to the student to ask } \\
\text { for constructive criticism } \\
\text { from the supervisor }\end{array}$ \\
\hline
\end{tabular}

Table 1 . Thesis responsibility survey items 


\begin{tabular}{|l|c|r|r|}
\hline \multicolumn{1}{|c|}{ Academic level } & $\mathbf{\%}$ & $\begin{array}{c}\text { Mean } \\
\text { Supervision } \\
\text { experience }\end{array}$ & $\begin{array}{c}\text { SD } \\
\text { Supervision } \\
\text { experience }\end{array}$ \\
\hline A (Associate Lecturer) & 0 & - & - \\
\hline B (Lecturer) & 16 & 1.00 & 0.00 \\
\hline C (Senior Lecturer) & 28 & 1.86 & 0.90 \\
\hline D (Associate Professor) & 24 & 2.17 & 0.41 \\
\hline E (Professor) & 32 & 2.50 & 0.76 \\
\hline
\end{tabular}

Table 2. Thesis supervisor experience $(\mathrm{n}=25)$

A total of 122 thesis students participated in the present study (indicating a response rate of over $95 \%$ of all enrolled thesis students). Of these students, $87.7 \%$ were male and $12.3 \%$ were female. The international student component was $12.3 \%$ (80\% male and $20 \%$ female) with the remaining $87.7 \%$ being domestic students $(88.8 \%$ male and $11.2 \%$ female). The issues related to low Australian female student attraction to engineering and low subsequent retention are evident from the participating student breakdown.

Twenty five academic staff members currently supervising undergraduate engineering thesis students completed the survey. This represents a $76 \%$ response rate. Post survey follow-up discussions were held with supervising staff $(n=7)$ (i.e. $28 \%$ of supervisors participating in the study) to ascertain the motivations related to their supervisory expectations and styles. These discussions were also very valuable in elucidating some of the reasons for observed discrepancies between university expectations and current supervisory staff practices.

\section{Results and Discussion}

The survey data obtained from all students $(\mathrm{n}=122)$ is presented in Table 3, with the gender breakdown of these responses provided in Tables 4 and 5 . International student responses are detailed in Table 6 . The arithmetic mean and standard deviation (SD) of the responses to each item are also presented in these tables. These are calculated from the participant responses in the -2 to +2 score range as indicated in Table 1. Immediately evident from this data is that there are some distinct differences in expectations of thesis responsibilities between the male, female and international student sub-groups. Overall, the biggest disagreement between student responses appears to centre on the issue of requesting and providing feedback on thesis drafts (i.e. survey item 12). There are a large range of responses spread between this being the supervisor's and the student's responsibility.

\begin{tabular}{|c|c|c|c|c|c|c|c|}
\hline Item & $\begin{array}{l}\text { Strongly agree } \\
\text { this is the } \\
\text { supervisor's } \\
\text { responsibility }\end{array}$ & $\begin{array}{l}\text { Mildly agree this } \\
\text { is the supervisor's } \\
\text { responsibility }\end{array}$ & Neutral & $\begin{array}{l}\text { Mildly agree this } \\
\text { is the student's } \\
\text { responsibility }\end{array}$ & $\begin{array}{l}\text { Strongly agree } \\
\text { this is the } \\
\text { student's } \\
\text { responsibility }\end{array}$ & Mean & SD \\
\hline 1 & $3.3 \%$ & $17.2 \%$ & $34.4 \%$ & $34.4 \%$ & $10.7 \%$ & 0.32 & 0.99 \\
\hline 2 & $3.3 \%$ & $38.5 \%$ & $38.5 \%$ & $16.4 \%$ & $2.5 \%$ & -0.24 & 0.86 \\
\hline 3 & $14.8 \%$ & $32.0 \%$ & $27.0 \%$ & $21.3 \%$ & $4.9 \%$ & -0.30 & 1.11 \\
\hline 4 & $32.0 \%$ & $41.8 \%$ & $13.1 \%$ & $9.0 \%$ & $4.1 \%$ & -0.89 & 1.08 \\
\hline 5 & $9.8 \%$ & $21.3 \%$ & $41.0 \%$ & $18.9 \%$ & $9.0 \%$ & -0.04 & 1.08 \\
\hline 6 & $3.3 \%$ & $10.7 \%$ & $38.5 \%$ & $36.1 \%$ & $11.5 \%$ & 0.42 & 0.94 \\
\hline 7 & $8.2 \%$ & $25.4 \%$ & $34.4 \%$ & $22.1 \%$ & $9.8 \%$ & 0.00 & 1.10 \\
\hline 8 & $1.6 \%$ & $10.7 \%$ & $22.1 \%$ & $33.6 \%$ & $31.1 \%$ & 0.83 & 1.05 \\
\hline 9 & $1.6 \%$ & $4.9 \%$ & $15.6 \%$ & $36.1 \%$ & $41.8 \%$ & 1.11 & 0.96 \\
\hline 10 & $2.5 \%$ & $21.3 \%$ & $37.7 \%$ & $30.3 \%$ & $8.2 \%$ & 0.20 & 0.95 \\
\hline 11 & $4.1 \%$ & $7.4 \%$ & $12.3 \%$ & $36.1 \%$ & $40.2 \%$ & 1.01 & 1.09 \\
\hline 12 & $9.0 \%$ & $27.9 \%$ & $20.5 \%$ & $32.8 \%$ & $9.8 \%$ & 0.07 & 1.17 \\
\hline
\end{tabular}

Table 3. Student survey responses; All $(n=122)$ 


\begin{tabular}{|c|c|c|c|c|c|c|c|}
\hline Item & $\begin{array}{l}\text { Strongly agree } \\
\text { this is the } \\
\text { supervisor's } \\
\text { responsibility }\end{array}$ & $\begin{array}{l}\text { Mildly agree this } \\
\text { is the supervisor's } \\
\text { responsibility }\end{array}$ & Neutral & $\begin{array}{l}\text { Mildly agree this } \\
\text { is the student's } \\
\text { responsibility }\end{array}$ & $\begin{array}{l}\text { Strongly agree } \\
\text { this is the } \\
\text { student's } \\
\text { responsibility }\end{array}$ & Mean & SD \\
\hline 1 & $1.9 \%$ & $17.8 \%$ & $33.6 \%$ & $37.4 \%$ & $9.3 \%$ & 0.35 & 0.94 \\
\hline 2 & $2.8 \%$ & $35.5 \%$ & $41.1 \%$ & $16.8 \%$ & $2.8 \%$ & -0.19 & 0.85 \\
\hline 3 & $15.0 \%$ & $31.8 \%$ & $26.2 \%$ & $21.5 \%$ & $5.6 \%$ & -0.29 & 1.13 \\
\hline 4 & $31.8 \%$ & $40.2 \%$ & $13.1 \%$ & $10.3 \%$ & $4.7 \%$ & -0.84 & 1.13 \\
\hline 5 & $8.4 \%$ & $21.5 \%$ & $41.1 \%$ & $18.7 \%$ & $10.3 \%$ & 0.01 & 1.08 \\
\hline 6 & $2.8 \%$ & $11.2 \%$ & $38.3 \%$ & $36.4 \%$ & $11.2 \%$ & 0.42 & 0.93 \\
\hline 7 & $8.4 \%$ & $23.4 \%$ & $35.5 \%$ & $22.4 \%$ & $9.3 \%$ & 0.01 & 1.09 \\
\hline 8 & $0.9 \%$ & $12.1 \%$ & $20.6 \%$ & $34.6 \%$ & $30.8 \%$ & 0.83 & 1.04 \\
\hline 9 & $1.9 \%$ & $5.6 \%$ & $15.9 \%$ & $33.6 \%$ & $43.0 \%$ & 1.10 & 0.99 \\
\hline 10 & $2.8 \%$ & $21.5 \%$ & $38.3 \%$ & $29.0 \%$ & $8.4 \%$ & 0.19 & 0.96 \\
\hline 11 & $3.7 \%$ & $7.5 \%$ & $10.3 \%$ & $36.4 \%$ & $42.1 \%$ & 1.06 & 1.08 \\
\hline 12 & $7.5 \%$ & $27.1 \%$ & $23.4 \%$ & $33.6 \%$ & $8.4 \%$ & 0.08 & 1.12 \\
\hline
\end{tabular}

Table 4. Student survey responses; Male $(\mathrm{n}=107)$

\begin{tabular}{|c|c|c|c|c|c|c|c|}
\hline Item & $\begin{array}{l}\text { Strongly agree } \\
\text { this is the } \\
\text { supervisor's } \\
\text { responsibility }\end{array}$ & $\begin{array}{l}\text { Mildly agree this } \\
\text { is the supervisor's } \\
\text { responsibility }\end{array}$ & Neutral & $\begin{array}{l}\text { Mildly agree this } \\
\text { is the student's } \\
\text { responsibility }\end{array}$ & $\begin{array}{l}\text { Strongly agree } \\
\text { this is the } \\
\text { student's } \\
\text { responsibility }\end{array}$ & Mean & SD \\
\hline 1 & $13.3 \%$ & $13.3 \%$ & $40.0 \%$ & $13.3 \%$ & $20.0 \%$ & 0.13 & 1.30 \\
\hline 2 & $6.7 \%$ & $60.0 \%$ & $20.0 \%$ & $13.3 \%$ & $0.0 \%$ & -0.60 & 0.83 \\
\hline 3 & $13.3 \%$ & $33.3 \%$ & $33.3 \%$ & $20.0 \%$ & $0.0 \%$ & -0.40 & 0.99 \\
\hline 4 & $33.3 \%$ & $53.3 \%$ & $13.3 \%$ & $0.0 \%$ & $0.0 \%$ & -1.20 & 0.68 \\
\hline 5 & $20.0 \%$ & $20.0 \%$ & $40.0 \%$ & $20.0 \%$ & $0.0 \%$ & -0.40 & 1.06 \\
\hline 6 & $6.7 \%$ & $6.7 \%$ & $40.0 \%$ & $33.3 \%$ & $13.3 \%$ & 0.40 & 1.06 \\
\hline 7 & $6.7 \%$ & $40.0 \%$ & $20.0 \%$ & $20.0 \%$ & $13.3 \%$ & -0.07 & 1.22 \\
\hline 8 & $6.7 \%$ & $0.0 \%$ & $33.3 \%$ & $26.7 \%$ & $33.3 \%$ & 0.80 & 1.15 \\
\hline 9 & $0.0 \%$ & $0.0 \%$ & $13.3 \%$ & $53.3 \%$ & $33.3 \%$ & 1.20 & 0.68 \\
\hline 10 & $0.0 \%$ & $20.0 \%$ & $33.3 \%$ & $40.0 \%$ & $6.7 \%$ & 0.33 & 0.90 \\
\hline 11 & $6.7 \%$ & $6.7 \%$ & $26.7 \%$ & $33.3 \%$ & $26.7 \%$ & 0.67 & 1.18 \\
\hline 12 & $20.0 \%$ & $33.3 \%$ & $0.0 \%$ & $26.7 \%$ & $20.0 \%$ & -0.07 & 1.53 \\
\hline
\end{tabular}

Table 5. Student survey responses; Female $(n=15)$

\begin{tabular}{|c|r|r|r|r|r|r|r|}
\hline Item & $\begin{array}{c}\text { Strongly agree } \\
\text { this is the } \\
\text { supervisor's } \\
\text { responsibility }\end{array}$ & $\begin{array}{c}\text { Mildly agree this } \\
\text { is the supervisor's } \\
\text { responsibility }\end{array}$ & Neutral & $\begin{array}{c}\text { Mildly agree } \\
\text { this is the } \\
\text { student's } \\
\text { responsibility }\end{array}$ & $\begin{array}{c}\text { Strongly agree } \\
\text { this is the } \\
\text { student's } \\
\text { responsibility }\end{array}$ & Mean & SD \\
\hline 1 & $0.0 \%$ & $33.3 \%$ & $20.0 \%$ & $26.7 \%$ & $20.0 \%$ & 0.33 & 1.18 \\
\hline 2 & $6.7 \%$ & $40.0 \%$ & $40.0 \%$ & $13.3 \%$ & $0.0 \%$ & -0.40 & 0.83 \\
\hline 3 & $46.7 \%$ & $26.7 \%$ & $26.7 \%$ & $0.0 \%$ & $6.7 \%$ & -1.00 & 1.20 \\
\hline 4 & $66.7 \%$ & $20.0 \%$ & $13.3 \%$ & $0.0 \%$ & $0.0 \%$ & -1.53 & 0.74 \\
\hline 5 & $13.3 \%$ & $6.7 \%$ & $53.3 \%$ & $13.3 \%$ & $13.3 \%$ & 0.07 & 1.16 \\
\hline 6 & $13.3 \%$ & $20.0 \%$ & $46.7 \%$ & $13.3 \%$ & $6.7 \%$ & -0.20 & 1.08 \\
\hline 7 & $33.3 \%$ & $26.7 \%$ & $26.7 \%$ & $0.0 \%$ & $13.3 \%$ & -0.67 & 1.35 \\
\hline 8 & $0.0 \%$ & $20.0 \%$ & $13.3 \%$ & $33.3 \%$ & $33.3 \%$ & 0.80 & 1.15 \\
\hline 9 & $6.7 \%$ & $6.7 \%$ & $40.0 \%$ & $26.7 \%$ & $20.0 \%$ & 0.47 & 1.13 \\
\hline 10 & $13.3 \%$ & $33.3 \%$ & $33.3 \%$ & $20.0 \%$ & $0.0 \%$ & -0.40 & 0.99 \\
\hline 11 & $20.0 \%$ & $20.0 \%$ & $20.0 \%$ & $13.3 \%$ & $26.7 \%$ & 0.07 & 1.53 \\
\hline 12 & $13.3 \%$ & $53.3 \%$ & $20.0 \%$ & $0.0 \%$ & $13.3 \%$ & -0.53 & 1.19 \\
\hline
\end{tabular}

Table 6. Student survey responses; International $(\mathrm{n}=15)$ 
The thesis supervisor survey data obtained $(n=25)$ is presented in Table 7. Significant differences in the responses of junior and senior academics are evident in the data collected. To examine these, the thesis supervisor survey data for academic levels $\mathrm{D}$ and $\mathrm{E}$ are provided separately in Table 8 . The general trend observed was that at higher academic level, the difference between student and supervisor responses is greater.

\begin{tabular}{|c|r|r|r|r|r|r|r|}
\hline Item & $\begin{array}{c}\text { Strongly agree } \\
\text { this is the } \\
\text { supervisor's } \\
\text { responsibility }\end{array}$ & $\begin{array}{c}\text { Mildly agree this } \\
\text { is the supervisor's } \\
\text { responsibility }\end{array}$ & Neutral & $\begin{array}{c}\text { Mildly agree this } \\
\text { is the student's } \\
\text { responsibility }\end{array}$ & $\begin{array}{c}\text { Strongly agree } \\
\text { this is the } \\
\text { student's } \\
\text { responsibility }\end{array}$ & Mean & SD \\
\hline 1 & $52.0 \%$ & $24.0 \%$ & $20.0 \%$ & $4.0 \%$ & $0.0 \%$ & -1.24 & 0.93 \\
\hline 2 & $28.0 \%$ & $40.0 \%$ & $24.0 \%$ & $4.0 \%$ & $4.0 \%$ & -0.84 & 1.03 \\
\hline 3 & $28.0 \%$ & $36.0 \%$ & $12.0 \%$ & $20.0 \%$ & $4.0 \%$ & -0.64 & 1.22 \\
\hline 4 & $72.0 \%$ & $16.0 \%$ & $12.0 \%$ & $0.0 \%$ & $0.0 \%$ & -1.60 & 0.71 \\
\hline 5 & $56.0 \%$ & $24.0 \%$ & $16.0 \%$ & $4.0 \%$ & $0.0 \%$ & -1.32 & 0.90 \\
\hline 6 & $24.0 \%$ & $32.0 \%$ & $20.0 \%$ & $16.0 \%$ & $8.0 \%$ & -0.48 & 1.26 \\
\hline 7 & $12.0 \%$ & $32.0 \%$ & $32.0 \%$ & $16.0 \%$ & $8.0 \%$ & -0.24 & 1.13 \\
\hline 8 & $8.0 \%$ & $8.0 \%$ & $44.0 \%$ & $24.0 \%$ & $16.0 \%$ & 0.32 & 1.11 \\
\hline 9 & $8.0 \%$ & $16.0 \%$ & $20.0 \%$ & $12.0 \%$ & $44.0 \%$ & 0.68 & 1.41 \\
\hline 10 & $8.0 \%$ & $28.0 \%$ & $44.0 \%$ & $12.0 \%$ & $8.0 \%$ & -0.16 & 1.03 \\
\hline 11 & $12.0 \%$ & $8.0 \%$ & $16.0 \%$ & $36.0 \%$ & $28.0 \%$ & 0.60 & 1.32 \\
\hline 12 & $24.0 \%$ & $24.0 \%$ & $16.0 \%$ & $24.0 \%$ & $12.0 \%$ & -0.24 & 1.39 \\
\hline
\end{tabular}

Table 7. Supervisor survey responses; All academic levels $(n=25)$

\begin{tabular}{|c|r|r|r|r|r|r|r|}
\hline Item & $\begin{array}{c}\text { Strongly agree } \\
\text { this is the } \\
\text { supervisor's } \\
\text { responsibility }\end{array}$ & $\begin{array}{c}\text { Mildly agree this } \\
\text { is the supervisor's } \\
\text { responsibility }\end{array}$ & Neutral & $\begin{array}{c}\text { Mildly agree } \\
\text { this is the } \\
\text { student's } \\
\text { responsibility }\end{array}$ & $\begin{array}{c}\text { Strongly agree } \\
\text { this is the } \\
\text { student's } \\
\text { responsibility }\end{array}$ & Mean & SD \\
\hline 1 & $64.3 \%$ & $21.4 \%$ & $7.1 \%$ & $7.1 \%$ & $0.0 \%$ & -1.43 & 0.94 \\
\hline 2 & $35.7 \%$ & $42.9 \%$ & $14.3 \%$ & $0.0 \%$ & $7.1 \%$ & -1.00 & 1.11 \\
\hline 3 & $35.7 \%$ & $28.6 \%$ & $7.1 \%$ & $21.4 \%$ & $7.1 \%$ & -0.64 & 1.39 \\
\hline 4 & $78.6 \%$ & $14.3 \%$ & $7.1 \%$ & $0.0 \%$ & $0.0 \%$ & -1.71 & 0.61 \\
\hline 5 & $64.3 \%$ & $28.6 \%$ & $7.1 \%$ & $0.0 \%$ & $0.0 \%$ & -1.57 & 0.65 \\
\hline 6 & $35.7 \%$ & $35.7 \%$ & $7.1 \%$ & $14.3 \%$ & $7.1 \%$ & -0.79 & 1.31 \\
\hline 7 & $21.4 \%$ & $21.4 \%$ & $28.6 \%$ & $14.3 \%$ & $14.3 \%$ & -0.21 & 1.37 \\
\hline 8 & $14.3 \%$ & $7.1 \%$ & $42.9 \%$ & $21.4 \%$ & $14.3 \%$ & 0.14 & 1.23 \\
\hline 9 & $7.1 \%$ & $14.3 \%$ & $21.4 \%$ & $14.3 \%$ & $42.9 \%$ & 0.71 & 1.38 \\
\hline 10 & $7.1 \%$ & $28.6 \%$ & $42.9 \%$ & $14.3 \%$ & $7.1 \%$ & -0.14 & 1.03 \\
\hline 11 & $21.4 \%$ & $7.1 \%$ & $14.3 \%$ & $35.7 \%$ & $21.4 \%$ & 0.29 & 1.49 \\
\hline 12 & $28.6 \%$ & $28.6 \%$ & $7.1 \%$ & $21.4 \%$ & $14.3 \%$ & -0.36 & 1.50 \\
\hline
\end{tabular}

Table 8. Supervisor survey responses; Academic levels D \& E ( $n=14)$

\subsection{Comparison of Thesis Student and Supervisor Expectations}

The survey responses of all students and thesis supervisors are compared in Table 9. The primary responsibility for each thesis element as indicated by each party is shown as is the difference in means for each survey item. Hypothesis testing was performed to determine whether the difference in response means by each sub-group was statistically significant. Immediately clear from the data in Table 9 is that students and supervisors display a rating bias toward placing primary responsibility for many thesis tasks upon themselves. This is not to say that their ratings always indicate they themselves are primarily responsible, but rather that even when they rate the other party primarily responsible, they do so with less severity than the other party views this responsibility. There exists significant disagreement between supervisors and student expectations regarding who is primarily responsible for many elements of the thesis. The overall responsibility ratings for these groups are clearly at odds with a statistically significant difference in overall means evident. 


\begin{tabular}{|c|l|c|r|r|}
\hline Item & \multicolumn{1}{|c|}{ Theme } & $\begin{array}{c}\text { Supervisor } \\
\text { reported } \\
\text { Responsibility }\end{array}$ & $\begin{array}{c}\text { Student } \\
\text { reported } \\
\text { Responsibility }\end{array}$ & $\begin{array}{c}\text { Difference in means } \\
\text { (student-supervisor) }\end{array}$ \\
\hline 1 & Topic selection & Supervisor & Student & $1.56^{*}$ \\
\hline 2 & Choice of theoretical frame of reference & Supervisor & Supervisor & $0.60^{*}$ \\
\hline 3 & Research plan development & Supervisor & Supervisor & 0.34 \\
\hline 4 & Ensuring access to necessary facilities & Supervisor & Supervisor & $0.71^{*}$ \\
\hline 5 & Professional vs personal relationship & Professional & Professional & $1.28^{*}$ \\
\hline 6 & Initiation of meetings & Supervisor & Student & $0.90^{*}$ \\
\hline 7 & Checking on progress & Supervisor & Equal & 0.24 \\
\hline 8 & $\begin{array}{l}\text { Termination of thesis for poorly } \\
\text { performing students }\end{array}$ & Student & Student & $0.51^{*}$ \\
\hline 9 & Finishing the thesis on time & Student & Student & 0.43 \\
\hline 10 & Methodology and content of the thesis & Supervisor & Student & 0.36 \\
\hline 11 & Thesis writing & Student & Student & 0.41 \\
\hline 12 & Requesting drafts/feedback on the thesis & Supervisor & Student & 0.31 \\
\hline Overall & & Supervisor & Student & $0.64^{*}$ \\
\hline
\end{tabular}

* indicates a statistically significant difference in means at $\alpha=0.05$

Table 9. Comparison of student $(n=122)$ and supervisor $(m=25)$ survey responses

The group of female student participants also follow the observed response bias trend (as evidenced by Table 10) but are generally better aligned with the supervisor responses than the male students. The exception to this is in the areas of taking responsibility for thesis method, content and completion (i.e. survey items 9 and 10) which female students rate slightly stronger.

\begin{tabular}{|c|l|c|r|r|}
\hline Item & \multicolumn{1}{|c|}{ Theme } & $\begin{array}{c}\text { Supervisor } \\
\text { reported } \\
\text { Responsibility }\end{array}$ & $\begin{array}{c}\text { Female Student } \\
\text { reported } \\
\text { Responsibility }\end{array}$ & $\begin{array}{r}\text { Difference in means } \\
\text { (student-supervisor) }\end{array}$ \\
\hline 1 & Topic selection & Supervisor & Student & $1.37^{*}$ \\
\hline 2 & Choice of theoretical frame of reference & Supervisor & Supervisor & 0.24 \\
\hline 3 & Research plan development & Supervisor & Supervisor & 0.24 \\
\hline 4 & Ensuring access to necessary facilities & Supervisor & Supervisor & $0.40^{* *}$ \\
\hline 5 & Professional vs personal relationship & Professional & Professional & $0.92^{*}$ \\
\hline 6 & Initiation of meetings & Supervisor & Student & $0.88^{*}$ \\
\hline 7 & Checking on progress & Supervisor & Supervisor & 0.17 \\
\hline 8 & $\begin{array}{l}\text { Termination of thesis for poorly } \\
\text { performing students }\end{array}$ & Student & Student & 0.48 \\
\hline 9 & Finishing the thesis on time & Student & Student & 0.52 \\
\hline 10 & Methodology and content of the thesis & Supervisor & Student & 0.49 \\
\hline 11 & Thesis writing & Student & Student & 0.07 \\
\hline 12 & Requesting drafts/feedback on the thesis & Supervisor & Supervisor & 0.17 \\
\hline Overall & & Supervisor & Student & $0.50^{*}$ \\
\hline
\end{tabular}

$*$ indicates a statistically significant difference in means at $\alpha=0.05$

** indicates a statistically significant difference in means at $\alpha=0.1$

Table 10. Comparison of female student $(n=15)$ and supervisor $(m=25)$ survey responses

International student responses (see the comparison in Table 11) were often at odds, in terms of their survey responses, with the remainder of the student cohort. They indicated a much stronger reliance on their supervisors to take primary responsibility, particularly in the areas of monitoring progress, dictating the methods employed, content of the thesis and obtaining feedback (i.e. items 7, 10 and 12). The strength of their rating of these items as being the supervisor's responsibility exceeded that of even the supervisors themselves. International students considered many of the tasks associated with the thesis (e.g. planning the research approach, initiating meetings etc) to be the responsibility of the supervisor. 
Even with regard to writing the thesis, it is clear that international students expect significant assistance from their supervisors. Many international students (40\%) rated this as the supervisor's responsibility with the mean barely scraping into the student responsibility response region. International students were also the only sub-group (including supervisors) who believed that a close personal, rather than professional relationship was essential for successful thesis supervision.

As previously indicated, there are distinct differences in the survey responses and thesis supervision practices of junior and senior academic staff. When comparing the responses of senior academic staff with student perceptions (Table 12), it is clear that there is greater disagreement regarding thesis responsibility expectations between these groups. Whether this is educationally detrimental of course depends on how well senior academic supervisory practices are aligned with university expectations and sound pedagogical approaches.

\begin{tabular}{|c|l|c|c|r|}
\hline Item & \multicolumn{1}{|c|}{ Theme } & $\begin{array}{c}\text { Supervisor } \\
\text { reported } \\
\text { Responsibility }\end{array}$ & $\begin{array}{c}\text { International } \\
\text { Student } \\
\text { reported } \\
\text { Responsibility }\end{array}$ & $\begin{array}{r}\text { Difference in means } \\
\text { (student-supervisor) }\end{array}$ \\
\hline 1 & Topic selection & Supervisor & Student & $1.57^{*}$ \\
\hline 2 & Choice of theoretical frame of reference & Supervisor & Supervisor & 0.44 \\
\hline 3 & Research plan development & Supervisor & Supervisor & -0.36 \\
\hline 4 & Ensuring access to necessary facilities & Supervisor & Supervisor & 0.07 \\
\hline 5 & Professional vs personal relationship & Professional & Personal & $0.39 *$ \\
\hline 6 & Initiation of meetings & Supervisor & Supervisor & -0.43 \\
\hline 7 & Checking on progress & Supervisor & Supervisor & 0.48 \\
\hline & Termination of thesis for poorly & Student & Student & -0.21 \\
\hline 8 & performing students & Student & Student & -0.24 \\
\hline 9 & Finishing the thesis on time & Supervisor & Supervisor & -0.53 \\
\hline 10 & Methodology and content of the thesis & Student & Student & -0.29 \\
\hline 11 & Thesis writing & Supervisor & Supervisor & 0.18 \\
\hline 12 & Requesting drafts/feedback on the thesis & Supervisor & Supervisor & \\
\hline Overall & & & & \\
\hline
\end{tabular}

$*$ indicates a statistically significant difference in means at $\alpha=0.05$

Table 11. Comparison of international student $(n=15)$ and supervisor $(m=25)$ survey responses

\begin{tabular}{|c|l|c|r|r|}
\hline Item & \multicolumn{1}{|c|}{ Theme } & $\begin{array}{c}\text { Supervisor } \\
\text { reported } \\
\text { Responsibility }\end{array}$ & $\begin{array}{r}\text { Student } \\
\text { reported } \\
\text { Responsibility }\end{array}$ & $\begin{array}{r}\text { Difference in means } \\
\text { (student-supervisor) }\end{array}$ \\
\hline 1 & Topic selection & Supervisor & Student & $1.75^{*}$ \\
\hline 2 & Choice of theoretical frame of reference & Supervisor & Supervisor & $0.76^{*}$ \\
\hline 3 & Research plan development & Supervisor & Supervisor & 0.34 \\
\hline 4 & Ensuring access to necessary facilities & Supervisor & Supervisor & $0.83^{*}$ \\
\hline 5 & Professional vs personal relationship & Professional & Professional & $1.53^{*}$ \\
\hline 6 & Initiation of meetings & Supervisor & Student & $1.20^{*}$ \\
\hline 7 & Checking on progress & Supervisor & Equal & 0.21 \\
\hline 8 & $\begin{array}{l}\text { Termination of thesis for poorly } \\
\text { performing students }\end{array}$ & Student & Student & $0.68^{*}$ \\
\hline 9 & Finishing the thesis on time & Student & Student & 0.40 \\
\hline 10 & Methodology and content of the thesis & Supervisor & Student & 0.35 \\
\hline 11 & Thesis $w r i t i n g$ & Student & Student & $0.72^{* *}$ \\
\hline 12 & Requesting drafts $/$ feedback on the thesis & Supervisor & Student & 0.42 \\
\hline Overall & & Supervisor & Student & $0.77^{*}$ \\
\hline
\end{tabular}

$*$ indicates a statistically significant difference in means at $\alpha=0.05$

$* *$ indicates a statistically significant difference in means at $\alpha=0.1$

Table 12. Comparison of all student $(n=122)$ and academic level D \& E supervisor $(n=14)$ survey responses 


\subsection{University Thesis Expectations}

Before launching into a comparison of the thesis student, thesis supervisor and university undergraduate thesis related expectations, it is necessary to clearly define what the university expectations (stated in the teaching and learning university policy documents, the thesis subject learning outcomes and accompanying university engineering thesis handbook) are. These expectations outline the sound pedagogical practice that should be applied to undergraduate supervision.

The first specific responsibility of students as stated in the UoW engineering thesis handbook is "developing a thesis proposal and plan for completing the project within the timeframe stipulated" (UoW Engineering Thesis handbook, 2017: page 8). The associated supervisor responsibilities are "supporting students in developing a proposal for their thesis within the required time frame" and "assisting students to develop a plan for completing their thesis within the stipulated time frame" (UoW Engineering Thesis handbook, 2017: page 8). The words 'supporting' and 'assisting' imply a secondary role and as such it is reasonable to interpret the thesis handbook rules to assert that the student has primary responsibility. Items 2 and 3 of the survey, pertaining to the choice of theoretical framework and planning of the research approach, clearly fall within this domain.

In selecting thesis topics, the options are of course largely limited by the set offered by supervising staff (although student-supervisor negotiations have resulted in numerous successful unlisted thesis topics being conducted in the past). The impetus to arrange a topic and consequently the final decision to accept a topic however, clearly place the responsibility for this task (i.e. survey item 1) principally with the students. Pedagogically, it is best practice to not be too prescriptive in defining the thesis topics for students. Investment in the thesis and subsequent improved academic performance has been observed to correlate well with a strong sense of ownership gained through student driven topic selection (Roberts \& Seaman, 2018). Since educating students regarding scientific method is a primary goal of the thesis subject, Harding (1973) suitably states that the lack of any direct involvement by the thesis student in identifying an area of research investigation omits the earlier stages of the hypothetico-deductive method.

Since the resources required to complete theses are predominantly under the control of academic staff and the educational institution, it is reasonable to state that ensuring access to necessary facilities (i.e. survey item 4) is the principal responsibility of the supervisor. This does not in any way however, diminish the related student responsibilities such as following through with inductions, appointments to use the facilities etc, but it does imply that primary responsibility logically lies with supervising staff.

The development of a close personal relationship with the student (i.e. survey item 5) is discouraged by university policy (UoW Close Personal Relationships Guidelines, 2017: page 8). In the case of higher degree research supervision it is expressly forbidden. The most significant implication of a failure to follow these guidelines is of course when this close personal relationship becomes a conflict of interest in terms of the supervisor's independence as an adjudicator of the quality of the student's work. There are also several prior thesis supervision studies (e.g. Ladany, 2014) that suggest that close personal relationships are extremely detrimental to successful thesis completion. In light of the conclusions of previous pedagogical studies and the possibility of a conflict of interest arising, this would indicate a professional student-supervisor relationship is prudent.

It is the responsibility of students to "arrange regular (usually weekly) time for meetings with his/her supervisor(s)" and to "maintain regular contact with the supervisor(s)" (UoW Engineering Thesis handbook, 2017: page 8) (i.e. survey item 6). The UoW thesis handbook also states that one of the supervisor responsibilities is to "maintain regular contact with students in order to monitor their progress" (UoW Engineering Thesis handbook, 2017: page 8). On the surface, it would appear therefore that survey item 6 is an equally shared responsibility. In determining primary responsibility however, the overarching condition that "The responsibility for successful Project Management lies with each student" (UoW Engineering Thesis handbook, 2017: page 9) must also be taken into consideration. On balance then, it is reasonable to again place principal responsibility for all elements related to project management, 
such as setting and keeping regular meetings (i.e. survey item 6), monitoring progress (i.e. item 7) and timely thesis completion (i.e. item 9) with the student. In their guide on research study success, Phillips and Pugh (2000) also concur that students must take responsibility for managing their own learning.

Although it is the responsibility of the supervisor to "advise students of inadequate progress or work below the standard generally required and suggesting appropriate remedial action" (UoW Engineering Thesis handbook, 2017: page 8), it is ultimately the student's decision to continue or terminate their enrolment in the thesis subject. If the student remains enrolled, the supervisor responsibilities to provide effective thesis guidance remain. The associated survey item (i.e. item 8 ) is therefore clearly the student's responsibility. It is alarming to note that over $64 \%$ of senior academic staff members do not rate this as solely the student's responsibility. In the present survey, many supervisors even reported they believed they were primarily responsible for terminating an undergraduate thesis if they thought the student would not succeed. In practice, several cases have been observed where students have fallen victim to supervising staff that simply stop investing their time to supervise a student they believed to be underperforming.

Please note that these interpretations of university policy and the thesis handbook are not to be taken to diminish the guiding responsibility of supervising staff. The UoW thesis handbook clearly states that "The overriding responsibility of supervisors is to provide continuing support to students throughout their research to enable them to produce a thesis reflective of their academic ability" (UoW Engineering Thesis handbook, 2017: page 8). Rather, the university expectations discussed ensure that thesis students can be properly assessed. If the bulk of the responsibility for each of the thesis tasks is assumed by the supervisor this then presents enormous difficulties in determining whether the related learning outcomes have been achieved by the student. If the thesis research plan for example is so rigidly 'guided' by the supervisor (i.e. the supervisor assumes primary responsibility) as to have no chance of being unsuccessful, then the student cannot fail to meet the associated learning outcome. If the student cannot fail to meet a learning outcome due to overly prescriptive supervision, then the student cannot be properly assessed as having met the conditions for a pass level performance in the thesis subject. Primary responsibility for any task that can be linked directly to any of the subject learning outcomes must necessarily remain the primary responsibility of the student. Table 13, which maps the various elements of a thesis to the learning outcomes of the thesis subject, illustrates this connection to the survey questions. The survey items are of course directly related to specific thesis tasks (or components) and can consequently be mapped directly to the thesis subject learning outcomes.

In addition to the components discussed previously, the supporting role of the supervisor also pertains to the methodology and content of the thesis (i.e. survey item 10) and the writing of the thesis (i.e. item 11). With the writing of the thesis in particular, the difference between supervisors assisting in the writing of the thesis and supervisors assisting the development of sound writing ability so the student is able to write their thesis, should be carefully noted. It is alarming that almost $43 \%$ of senior academic staff supervisors do not believe the writing of the thesis to be entirely the responsibility of the student. Demonstrated attainment of the associated learning outcome (i.e. written communication ability) by the student becomes near impossible when the supervisor assumes primary responsibility.

\begin{tabular}{|c|c|}
\hline Thesis component & Learning outcome \\
\hline Problem Definition & (i) Define clearly the aims and objectives of a given problem. \\
\hline Literature Review & $\begin{array}{l}\text { (ii) Retrieve and analyse previous work on related problems (critical } \\
\text { literature review). }\end{array}$ \\
\hline Research Plan & (iii) Formulate methods for problem solution. \\
\hline Research Implementation & $\begin{array}{l}\text { (iv) Plan, design and construct an experimental or theoretical procedure to } \\
\text { solve the problem. }\end{array}$ \\
\hline Data Analysis and Conclusions & (v) Collect data and evaluate findings. \\
\hline Communication and Presentation & (vi) Communicate conclusions and solutions verbally and in writing. \\
\hline
\end{tabular}

Table 13. Thesis assessment components mapped to thesis subject learning outcomes 
The provision and requesting of feedback on the thesis drafts (and associated assessment components) is necessarily a shared responsibility as it requires cooperation from both parties. The UoW engineering thesis handbook makes this clear by stating that students must "present required written material to the supervisor(s) in sufficient time to allow for comments and discussions before scheduled meetings" and in response supervisors must "provide timely and helpful written feedback to students on submitted assessment items and assisting students to develop solutions as problems are identified" (UoW Engineering Thesis handbook, 2017: page 8). It is necessary at this point to note that this feedback needs to consider not just the technical aspects of the student's work, but also the English language competency. The University's English Language Policy (ELP) states that "supervisors are responsible for providing students with constructive feedback on the quality of their English language communication" (UoW English Language Policy, 2014).

\subsection{Comparison of Thesis Student, Supervisor and University Expectations}

The student and thesis supervisor survey responses for each of the sub-groups examined is collated in Figure 1. Included in this plot are the university pedagogical expectations regarding undergraduate thesis responsibilities. Please note that the university ratings provided indicate the directionality of expected responsibility only.

Generally, it is evident from this plot that there exists a clear bias toward an expectation that thesis supervisors take primary responsibility. Of all the student sub-groups, International students displayed the strongest expectations that the supervisor will take responsibility for many aspects of their thesis. Overall however, the bias toward supervisor responsibility is most pronounced in the supervisor responses. This trend is particularly pronounced in the responses of senior academic staff.

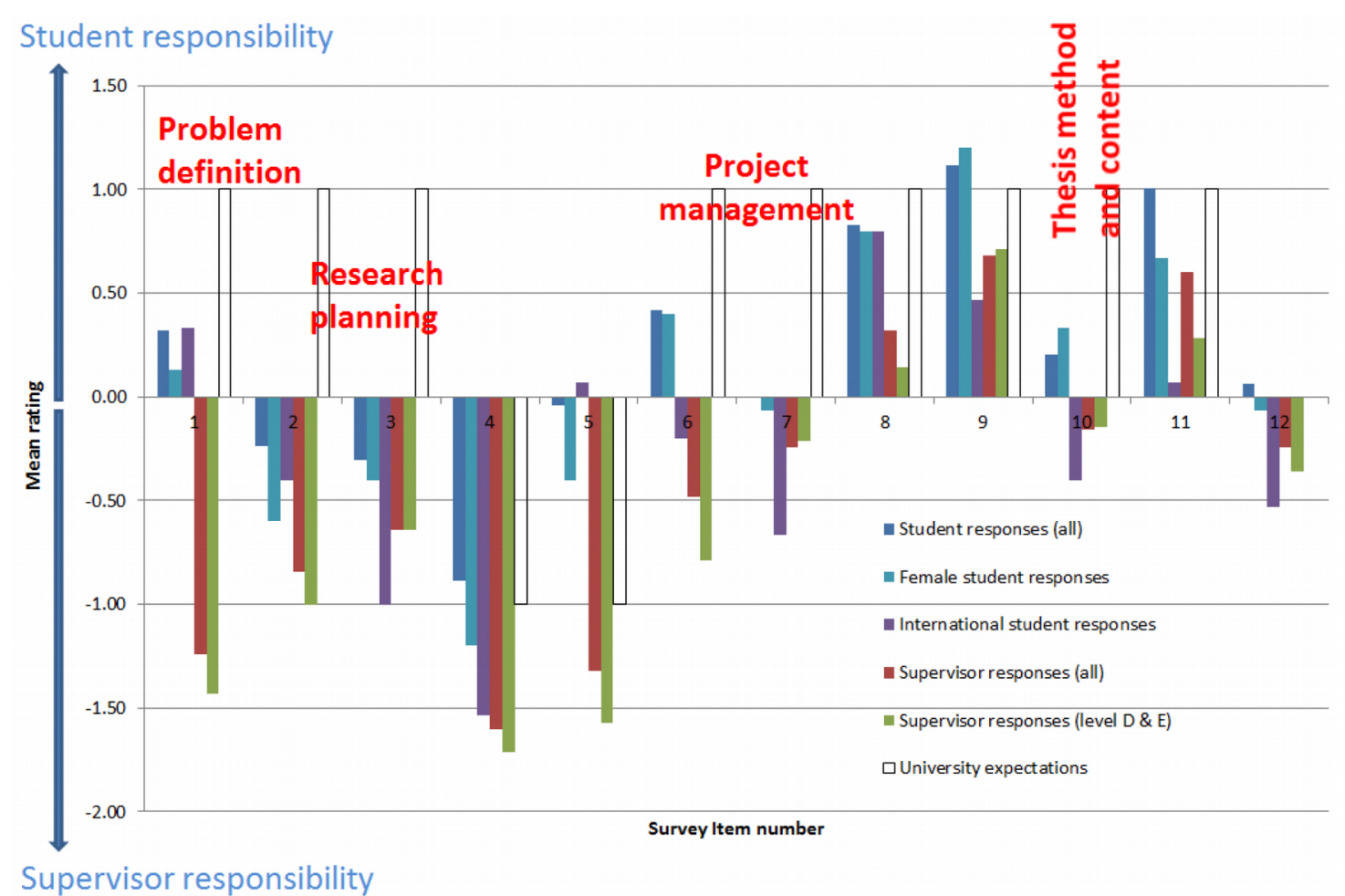

Figure 1. Student, supervisor and university thesis responsibility expectations. Note: The university rating provided indicates the directionality of expected responsibility only

As previously discussed, many elements of a thesis (as mapped in Table 13) should be primarily the responsibility of the student. This is a necessary condition in order for them to be able to demonstrate attainment of the associated learning outcomes. It is clear from Figure 1 that this requirement is often incongruent with the expectations of students and academic staff. Several particularly noteworthy areas 
where university and pedagogical expectations are at odds with student and/or supervisor responses (and consequently practices) are indicated in Figure 1. It is especially alarming that student expectations regarding thesis responsibility are better aligned with the university requirements than those expressed by the supervising staff. The student position can be somewhat excused as they find themselves torn between the responsibilities stated in the thesis handbook (and associated university policies) and those dictated by the supervising staff. If undergraduate thesis supervisor expectations were well aligned with university requirements, then this would point squarely at a pressing need to better communicate thesis responsibilities to students. Instead, the present outcome indicates that academic staff supervising undergraduate theses are driven by agendas that do not align well with the sound pedagogy stipulated by the educational institution.

Through follow-up discussions, it became apparent that many academic staff members appear to operate undergraduate thesis supervision with the same agenda as they do their higher degree, post-doctoral and personal research. A key expectation evident from the post-survey discussions with supervising staff was that useful research data that complemented existing research projects would result from each undergraduate thesis supervised. Some staff expressed what they thought to be the widely held belief that publications were expected from all research student work, including undergraduate thesis research. These views are consistent with the observed survey results. When supervisors are armed with such beliefs, they necessarily take primary responsibility for topic selection, research planning and implementation to ensure their expectations are met and research output is produced at the required standard. The staff involved in the post-survey discussions invariably pointed to the pressure to publish as a key driver for this behaviour.

This situation is of course clearly extremely detrimental from an educational perspective. With supervisors taking primary responsibility for many critical elements of the thesis, any compliant student will not experience great difficulty in appearing to meet the associated learning outcomes. Some data that illustrates this problem may be found by examining past thesis student performance. The past 10 engineering thesis subject cohorts supervised $(n=326)$ show a mean failure rate of less than $2.4 \%$. Almost all of these thesis subject failures are due to non-submission of theses (and typically non-attendance and non-submission of most other associated assessment items also). The mean failure rate of students submitting a final thesis for examination is $0.18 \%$ (and this non-zero result is entirely a consequence of the authors' own supervision practices). The argument that students are well motivated to succeed, as the thesis represents the conclusion of their degree, is often used to argue the case for such low failure rates in the thesis subject. This argument becomes far less convincing when the typical failure rate for other final year subjects (where the same motivation to succeed exists), of between $5-10 \%$, is considered. In light of the results of the present study, it is far more likely that the cause of this extremely low failure rate is due to supervisors taking too much control of the thesis away from their students.

\section{Conclusions}

Alignment between student and university expectations regarding undergraduate thesis responsibilities in the present study was generally poor. It is evident that International students in particular commence their undergraduate theses with strong expectations that their supervisor will assume primary responsibility for many aspects of the thesis. As previously discussed, many of these thesis elements are necessarily the student's responsibility. Relinquishing this responsibility puts many international students at risk of not adequately demonstrating the attainment of the thesis subject learning outcomes.

There exists even stronger disagreement between supervisor and university expectations than the university-student expectation discrepancy noted. The most alarming result of the present study is that academic staff thesis supervisors appear to be taking too much responsibility for the research being conducted by undergraduate thesis students. This diminishes the ability for an accurate assessment of adequate academic performance by making it difficult to determine whether learning outcomes are actually met by the student. This trend appears to be primarily driven by supervisor expectations that undergraduate thesis research would contribute to or result in publications. 
It is important for academic staff to remember the distinction between research and teaching. Undergraduate thesis students are not research assistants contributing to a larger research project, nor are they undertaking higher degree research where research output, rather than research process is primarily under assessment. The Doctor and Master of Philosophy degrees decree assessment criteria centred upon the student making an original and substantial contribution to a body of knowledge. Higher degree research is therefore research output focussed. In contrast to this, the undergraduate thesis subject is focussed on the demonstrated attainment of competency regarding the research process. This is clearly evident from the thesis subject learning outcomes and assuming sound constructive alignment, should also be at the heart of undergraduate thesis assessment.

As stated by Malcolm (2012, p574), "the [undergraduate] dissertation is an opportunity to practice previously developed research skills in a context designed to support a research experience" where "it is important that all aspects of the pedagogic practice of dissertation supervision support that objective." "Honours projects primarily represent a teaching and learning exercise, established for the benefit of students and not for the gratification of staff" (Stefani, Tariq, Heylings \& Butcher, 1997: page 284). Undergraduate research supervision approaches such as the action learning framework described in Stappenbelt (2016) can aid to facilitate minimisation of supervisor dominance of the thesis process. The aims of the action learning approach advocated in this work are to encourage self-exploration of the topic and move the learner toward the ultimate goal of autonomy.

The results of the present study need to be considered of course in light of the study limitations related to bias of the samples (i.e. being a single faculty, single institution study) and the consequent limited sample sizes. Through the authors' employment at other Australian institutions, cross-institutional benchmarking and collegial inter-institutional pedagogical discussion, the authors are convinced however, that the issues raised in this paper have farther reaching relevance throughout the sector than this smallscale study may suggest. Future work will undoubtedly include broadening the sampling base and increasing the sample size of this study. Further exploration of supervisor motivations and student perceptions of these have also been identified as pressing future research avenues.

Undergraduate research is concerned with research method. It should not be overly concerned with research output. What is desperately required is a renewed effort to focus the role of the supervisor toward, as Cook (1980: page 182) described well as providing "educational guidance, rather than instruction". Supervision requires more than just academic and research skills from the supervisors (Lessing, 2011). The power imbalance between supervisors and students (Manathunga, 2007; Armitage, 2007) means students are not well positioned to drive any required change. Remediation is consequently the responsibility of those providing the undergraduate thesis supervision.

\section{Acknowledgments}

The authors gratefully acknowledge the students and staff who participated in the present study. Particular thanks go to the academic staff who candidly expressed their views on undergraduate thesis supervision during the post-survey discussions.

\section{Declaration of Conflicting Interests}

The authors declared no potential conflicts of interest with respect to the research, authorship, and/or publication of this article.

\section{Funding}

The authors received no financial support for the research, authorship, and/or publication of this article. 


\section{References}

Australian Qualifications Framework Council (2013). Australian Qualifications Framework (2nd ed.). Available at: https://www.aqf.edu.au/aqf-second-edition-january-2013

Armitage, A. (2007), Supervisory power and postgraduate supervision. International Journal of Management Education, 6, 18-29. https://doi.org/10.3794/ijme.62.179

Aspland, T., Edwards, H., O’Leary, J., \& Ryan, J. (1999). Tracking New Directions in the Evaluation of Postgraduate Supervision. Innovative Higher Education, 24(2), 127-147.

https://doi.org/10.1023/B:IHIE.0000008150.75564.b3

Boyer Commission (1998). Re-inventing undergraduate education: A blueprint for America's research universities. Stony Brook, NY: Carnegie Foundation for University Teaching.

Brew, A., \& Jewell, E. (2012). Enhancing quality learning through experiences of research-based learning: Implications for academic development. International Journal for Academic Development, 17(1), 47-58. https://doi.org/10.1080/1360144X.2011.586461

Brew, A., \& Mintai, L. (2017). Academics' perceptions of the challenges and barriers to implement research-based experiences for undergraduates. Teaching in Higher Education, 22, 551-568. https://doi.org/10.1080/13562517.2016.1273216

Brew, A. (2013). Understanding the scope of undergraduate research: A framework for curricular and pedagogical decision-making. Higher Education, 66, 603-618. https://doi.org/10.1007/s10734-013-9624-x

Brown, R.D., \& Krager, L. (1985). Ethical issues in graduate education: faculty and student responsibilities. Journal of High Education, 56(4), 403-418. https://doi.org/10.1080/00221546.1985.11780701

Chin, C.M.M., Spowage, A.C., Yap, E.H., \& Lee, C.W. (2011). Developing a Project Management Methodology for Use in Doctoral Research Projects. Journal of Institutional Research South East Asia, 9(1).

Cornwall, M.G., Schmithals, F., \& Jacques, D. (Eds.) (1977). What is project orientation? an overview, Proceedings of the Seminar on Project-Orientation in Higher Education in Science, (1-16), University of Bremen, March 1976.

Cook, M.C.F. (1980). The role of the academic supervisor for undergraduate dissertations in science and science-related subjects. Studies in Higher Education, 5(2), 173-185.

https://doi.org/10.1080/03075078012331377206

Day, J., \& Bobeva, M. (2007). Applying performance management principles to a learning environment for undergraduate dissertations: A case study. The International Journal for Quality and Standards, 9, 217-239.

Derounian, J. (2011). Shall we dance? The importance of staff-student relationships to undergraduate dissertation preparation. Active Learning in Higher Education, 12(2), 91-100.

Evans, B. (2007). Doctoral education in Australia. In Powell, S., \& Green, H. (Eds.), The doctorate worldwide (105-119). Maidenhead: Society for Research into Higher Education \& Open University Press.

Evans, T., Lawson, A., McWilliam, E., \& Taylor, P. (2005). Understanding the management of doctoral studies in Australia as risk management. Studies in Research, 1, 1-11.

Fanelli, D. (2009). How many scientists fabricate and falsify research? A systematic review and meta-analysis of survey data. PLoS ONE, 4, e5738. https://doi.org/10.1371/journal.pone.0005738

Gatfield, T. (2005). An Investigation into PhD Supervisory Management Styles: Development of a Dynamic Conceptual Model and its Managerial Implications. Journal of Higher Education Policy and Management, 27(3), 311-325. https://doi.org/10.1080/13600800500283585 
Grimes, D.R. (2018). Modelling Science Trustworthiness Under Publish Or Perish Pressure. Royal Society Open Science, 5(1). https://doi.org/10.1098/rsos.171511

Halse, C. (2011). Becoming a supervisor: the impact of doctoral supervision on supervisors' learning. Studies in Higher Education, 36(5), 557-570. https: / / doi.org/10.1080/03075079.2011.594593

Harding, A.G. (1973). The objectives and structure of undergraduate projects. British Journal of Educational Technology, 4, 94-105. https://doi.org/10.1111/j.1467-8535.1973.tb00604.x

Holmberg, L. (2006). Coach, Consultant or Mother: Supervisors' views on quality in the supervision of bachelor theses. Quality in Higher Education, 12(2), 207-216. https:/ / doi.org/10.1080/13538320600916833

Hussain, A. (2011). Supervision and evaluation of research projects of graduate students - Realities and requirements. Journal of Quality \& Technology Management, 7(1), 123-136.

Jamieson, S., \& Gray, C. (2006). The supervision of undergraduate research students: Expectations of student and supervisor. Practice and Evidence of Scholarship of Teaching and Learning in Higher Education, 1, 37-59.

Kiley, M., \& Cumming, J. (2014). The impact of changing government policies and institutional practices on master's by coursework students in Australia: A viable pathway to the PhD?. Journal of Higher Education Policy and Management, 36, 99-111. https:/ / doi.org/10.1080/1360080X.2013.861052

Kiley, M., Boud, D., Cantwell, R., \& Manathunga, C. (2009). The role of honours in contemporary Australian higher education. Report commissioned by the Australian Learning and Teaching Council. Available at: http://www.aushons.anu.edu.au/

Kiley, M., Boud, D., Manathunga, C., \& Cantwell, R. (2011). Honouring the incomparable: Honours in Australian universities. Higher Education, 62, 619-633. https://doi.org/10.1007/s10734-011-9409-z

Ladany, N. (2014). The Ingredients of Supervisor Failure. Journal Of Clinical Psychology: In Session, 70(11), 1094-1103. https://doi.org/10.1002/jclp.22130

Lee, G., Clark, A.M., \& Thompson, D.R. (2013). Roses and thorns: authorship and the PhD by publication. Journal of clinical nursing, 22(2), 299-300. https://doi.org/10.1111/jocn.12008

Lee, N., \& Loton, D. (2017). Capstone purposes across disciplines. Studies in Higher Education, 1-17. https://doi.org/10.1080/03075079.2017.1371687

Lessing, A. (2011). The role of the supervisor in the supervisory process. South African Journal of Higher Education, 25(5), 921-936.

Lovitts, B.E. (2005). Being a good course-taker is not enough: A theoretical perspective on the transition to independent research. Studies in Higher Education, 30, 137-154.

https://doi.org/10.1080/03075070500043093

Malcolm, M. (2012). Examining the implications of learner and supervisor perceptions of undergraduate dissertation research in Business and Management. Teaching in Higher Education, 17(5), 565-576.

Manathunga, C. (2007). Supervision as mentoring: The role of power and boundary crossing. Studies in Continuing Education, 29, 207-221. https://doi.org/10.1080/01580370701424650

McPhail, J., \& Erwee, R. (2000). Developing professional relationships between supervisors and doctoral candidates. Australian Journal of Management and Organisational Behaviour, 3(1), 76-90.

Moses, I. (1985). Supervising postgraduates, Higher Education Research and Development Society of Australia. HERDSA, Green Guide 3, Kensington. 
Mudaly, R. (2012). Gazing Inward: Teaching in the Postgraduate Milieu. Alternation, 19(2), 38-56.

Phillips, E.M., \& Pugh, D.S. (2000). How to get a Ph.D - a handbook for students and their supervisors. Buckingham: Open University Press.

Roberts, L.D., \& Seaman, K. (2018). Good undergraduate dissertation supervision: perspectives of supervisors and dissertation coordinators. International Journal for Academic Development, 23(1), 28-40.

Rowley, J., \& Slack, F. (2004). What is the future for undergraduate dissertations?. Education and Training, 46(4), 176-81. https://doi.org/10.1108/00400910410543964

Ryan, Y., \& Whittle, J. (1997). Adapted the original Moses schema. Workshop in the Third Conference on Postgraduate Supervision. Gold Coast, Australia.

Sahoo, R., \& Mazid, A.M. (2009). Effective supervision of postgraduate engineering students at Central Queensland University. Industrial Technology, ICIT 2009, IEEE International Conference. Gippsland, Australia.

Stappenbelt, B. (2013). The effectiveness of the teaching-research nexus in facilitating student learning. Engineering Education: Journal of the Higher Education Academy , 8(1), 111-121.

Stappenbelt, B. (2016). Action Learning in Undergraduate Engineering Thesis Supervision. Journal of Technology and Science Education, 7(1), 5-25.

Stefani, L.A.J., Tariq, V.N., Heylings, D.J.A., \& Butcher, A.C. (1997). A comparison of tutor and student conceptions of undergraduate research project work. Assessment and Evaluation in Higher Education, 22, 271-288. https://doi.org/10.1080/0260293970220302

UoW Close Personal Relationships Guidelines (2017). University of Wollongong. Available at: https://www.uow.edu.au/about/policy/UOW058605.html

UoW Engineering Thesis handbook (2017). University of Wollongong. Available at: https://eis.uow.edu.au/mmm/current-students/undergraduate/thesis/index.html

UoW English Language Policy (2014). University of Wollongong, Available at: https://www.uow.edu.au/about/policy/learning/UOW187817.html

Vera, J., \& Briones, E. (2015). Students' perspectives on the process of supervision and assessment of undergraduate dissertations. Culture and Education, 27(4), 726-765.

https://doi.org/10.1080/11356405.2015.1089391

Published by OmniaScience (www.omniascience.com)

Journal of Technology and Science Education, 2019 (www.jotse.org)

(c) (i) (3)

Article's contents are provided on an Attribution-Non Commercial 4.0 Creative commons International License.

Readers are allowed to copy, distribute and communicate article's contents, provided the author's and JOTSE journal's names are included. It must not be used for commercial purposes. To see the complete licence contents, please visit https://creativecommons.org/licenses/by-nc/4.0/. 